\title{
Extraction of Eco-Friendly Natural Dyes from Tradescantia pallida Purpurea and Cynomorium coccineum Growing Naturally in Tunisia
}

\author{
Mahjoub Jabli* \\ Department of Textile Materials and Process Research (ENIM), National School of Engineers of Monastir, Tunisia
}

*Corresponding author: Mahjoub Jabli, Department of Textile Materials and Process Research (ENIM), National School of Engineers of Monastir, Monastir 5000, Tunisia

Submission: 笽 November 03, 2017; Published: 望䙹 January 09, 2018

\begin{abstract}
Natural dyes are considered as promising choice to develop green textile dyeing process. In this framework, different parts of various plants constitute potential sources of natural dyes that are characterized by their easy availability and abundant nature. In this present work, Tradescantia pallida purpurea and Cynomorium coccineum are considered, for the first time, as sources of natural dyes for textile dyeing. Their prepared aqueous methanolic extracts were chemically characterized for Their Total Phenolic Contents (TPC), Total Flavanoid Contents (TFC) and for their ability to quench reactive species through the $\mathrm{DPPH}^{*}$ radical scavenging activity. The results gleaned from the dosage experiments of TPC and TFC values are found, to be $52 \mathrm{mg} \mathrm{GAE} / \mathrm{g}$ extract and $4.05 \mathrm{mg} \mathrm{QE} / \mathrm{g}$ extract for the methanolic Cynomorium coccineum extract. However, in the case of Tradescantia pallida purpurea, the TPC and TFC values are equal to $33 \mathrm{mg} \mathrm{GAE} / \mathrm{g}$ extract and $4.88 \mathrm{mg}$ QE/g extract. These results demonstrate that the polyphenolic compounds are the most important functional components found in the studied plants. These aqueous extracts are, also, rich with flavonoids which are generally known for their coloring power when they are applied to textile materials. Tradescantia pallida purpurea gives a pH dependent color. It is red at $\mathrm{pH} 3$ and yellow at pH8. However, the resulted dye from Cynomorium coccineum is blue.
\end{abstract}

Keywords: Tradescantia pallida purpurea; Cynomorium coccineum; TPC; TFC; IC50

\section{Introduction}

The consumption of the natural products has improved due to the global development of maintaining good health and reducing the risk of disease [1-3]. In this setting, many plants were studied. As example, Tradescantia pallida purpurea has been shown to have spatial and seasonal bio monitoring characteristics for metal emissions from vehicle pollution [4]. The antho cyanins unpurified crude extracted from this plant was, also, investigated with regards to their preliminary spectroscopic and thermo-optical characterization [5]. Several species of the genus Tradescantia belonging to the Commelinaceae family are, additionally, used in ethnobotany and used as medicinal and ornamental purposes [6,7].

Another plant called Cynomorium coccineum L. is a nonphotosynthetic plant, spread over the south of Spain to the southern Italian coast, Sardinia, Sicily, Malta and from the West African coast to North African coast (The Canary Islands to Tunisia) [8-10]. It belongs to the family of Balanophoraceae. It is a blackish red leafless root parasitic plant [11]. It is known as a traditional medicine. It is valorized as a tonic and aphrodisiac [12] and it is reported to enclose a hypo tensive effect [13]. Hence, the majority of the studies have focused on the biological properties and it has performed with aqueous and ethanol extracts [14-17]. In this framework, the works of Antonella Rosa et al. [18] dealt with the study of the composition and effect on intestinal Caco-2 cell viability and lipid profile of fixed oil obtained from dried stems of the plant and oil isolation has been performed by supercritical fractioned extraction with $\mathrm{CO}_{2}$. However, to our knowledge, there is no data which was concentrated on the investigation of the extraction of dyes from Tradescantia pallida purpurea and Cynomorium coccineum fractions. Herein, for the first time, our study is carried out for the extraction of dyes from these plants. Their aqueous extract is characterized for their TFC, TPC values and the antioxidant activity.

\section{Materials and Methods}

\section{Chemicals and materials}

The fractions of Tradescantia pallida purpurea and Cynomorium coccineum (Figure 1) were collected from the region of Monastir Tunisia during 15 Mars-Avril. Chemicals such as Folin-Ciocalteu's reagent, gallic acid and 2, 2-diphenyl-1-picrylhydrazyl (DPPH) were purchased from Sigma-Aldrich. All other solvents and chemicals (Methanol, etc.) used in this study were of analytical grade [19].

\section{Preparation of Tradescantia pallida purpurea and} Cynomorium coccineum extracts

Fractions of Tradescantia pallida purpurea and Cynomorium coccineum, with weighted fresh mass, were extracted with absolute 
methanol for a period of $72 \mathrm{~h}$ at room temperature. After filtration, the fractions were evaporated using vacuum evaporator $\AA$ apparatus (Figure 2a) and the extracted fraction were, diluted with distilled water and used for the dyeing experiments. Tradescantia pallida purpurea gives a $\mathrm{pH}$ dependent color. It is red at $\mathrm{pH}_{3}$ and yellow at pH 8. However, the resulted dye from Cynomorium coccineum is blue (Figure 2).
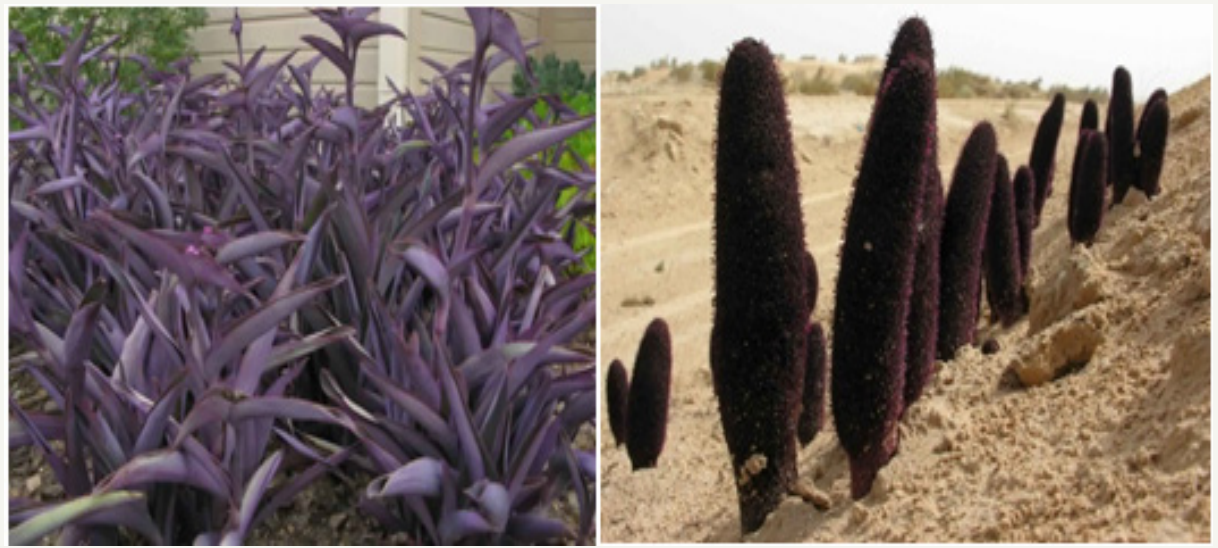

Figure 1: Photos of Tradescantia pallida purpurea and Cynomorium coccineum grown throughout the region of Monastir, Tunisia.

(a)

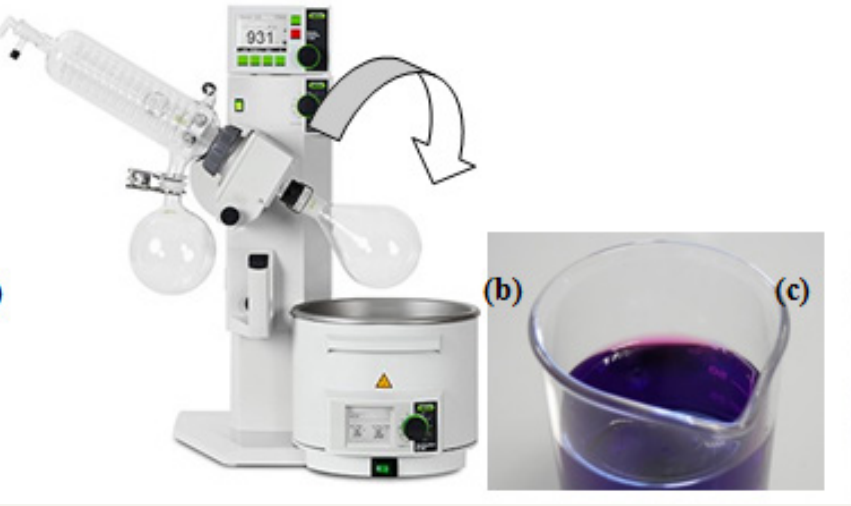

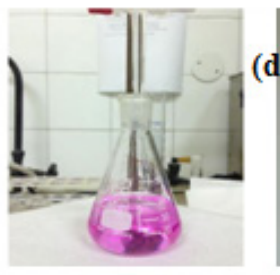

(d)

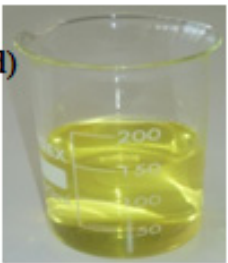

Figure 2: (a) Evaporator ${ }^{\circledR}$ apparatus, (b) dye extracted from Cynomorium coccineum fraction (c) dye extracted from Tradescantia pallida purpurea at $\mathrm{pH}=3$ and (d) dye extracted from Tradescantia pallida purpurea at $\mathrm{pH}=8$.

The TFC value of Tradescantia pallida purpurea and Cynomorium coccineum methanolic extracts was determined based on the method of Sun et al. [20] with some modifications. Briefly, $20 \mu \mathrm{L}$ of the methanolic extract $(1 \mathrm{mg} / \mathrm{m} \mathrm{L})$ or quercetin $(0.6-1 \mathrm{mg} /$ $\mathrm{m} \mathrm{L}$ ) was mixed with $30 \mu \mathrm{L}$ of $\mathrm{NaNO}_{2}(5 \%)$. After $6 \mathrm{~min}, 50 \mu \mathrm{L}$ of $\mathrm{AlCl}_{3}(10 \%)$ was added and the resulting mixture was allowed to be kept for another $5 \mathrm{~min}$. To the above mixture, $100 \mu \mathrm{L}$ of $\mathrm{NaOH}$ $(10 \%)$ was added and it has been incubated at room temperature for $15 \mathrm{~min}$. The absorbance was measured at $510 \mathrm{~nm}$ and TFC value was expressed as Quercetin Equivalents (QE).

\section{Free radical scavenging activity}

The radical scavenging assay 1,1-diphenyl-2-picrylhydrazyl (DPPH) was carried out according to the method described by $\mathrm{Yu}$ et al. [21]. Briefly, a volume of $1 \mathrm{~mL}$ of the as-prepared methanolic extract with different concentrations was mixed with $1 \mathrm{~mL}$ of DPPH solution $(0.1 \mathrm{mM}$ in ethanol). This mixture was incubated at room temperature for $30 \mathrm{~min}$, and the absorbance was measured at
$517 \mathrm{~nm}$. The concentration required to scavenge $50 \%$ of DPPH* was determined based on the ascorbic acid calibration curve.

\section{Results and Discussion}

\section{Dosage of TPC and TFC}

Table 1: TPC, TFC, and IC50 determined for Tradescantia pallida purpurea and Cynomorium coccineum methanolic extracts.

\begin{tabular}{|c|c|c|c|}
\hline Plants & $\begin{array}{c}\text { TPC (Mg QE/G } \\
\text { Extract) }\end{array}$ & $\begin{array}{c}\text { TFC (Mg GAE/G } \\
\text { Extract) }\end{array}$ & IC50 \\
\hline $\begin{array}{c}\text { Tradescantia } \\
\text { pallida purpurea }\end{array}$ & 33 & 4.88 & 3.7 \\
\hline $\begin{array}{c}\text { Cynomorium } \\
\text { coccineum }\end{array}$ & 52 & 4.05 & 7.5 \\
\hline
\end{tabular}

The results of the dosage experiments of TPC and TFC values are 52mg GAE/g extract and $4.05 \mathrm{mg} \mathrm{QE} / \mathrm{g}$ extract for the Methanolic cynomorium coccineum extract (Table 1). However, in the case of Tradescantia pallida purpurea, the values are equal to 33mg GAE/g extract and $4.88 \mathrm{mg} \mathrm{QE} / \mathrm{g}$ extract. This table demonstrated that 
the poly phenolic compounds are the most important functional components found in the studied extracts. These aqueous extracts are, also, rich with flavonoids which are generally known for their coloring power when they are applied to textile materials [22].

\section{DPPH radical scavenging assays}

The ability of Tradescantia pallida purpurea and Cynomorium coccineum fractions to quench reactive species by hydrogen donation was measured through the $\mathrm{DPPH}^{*}$ radical scavenging activity assay [21]. The evolution of DPPH scavenging activity (\%) against the studied Tradescantia pallida purpurea and Cynomorium coccineum methanolic fractions extract concentration is depicted in Figure 3. IC50 values were deduced as $3.7 \mathrm{mg} / \mathrm{mL}$ and $7.5 \mathrm{mg} / \mathrm{mL}$, respectively, for Tradescantia pallida purpurea and Cynomorium coccineum. These values are more important compared to Quercetin $(0.064 \mathrm{mg} / \mathrm{m} \mathrm{L})$. As, also, observed, the aqueous extract showed a concentration-dependent DPPH* radical scavenging activity.
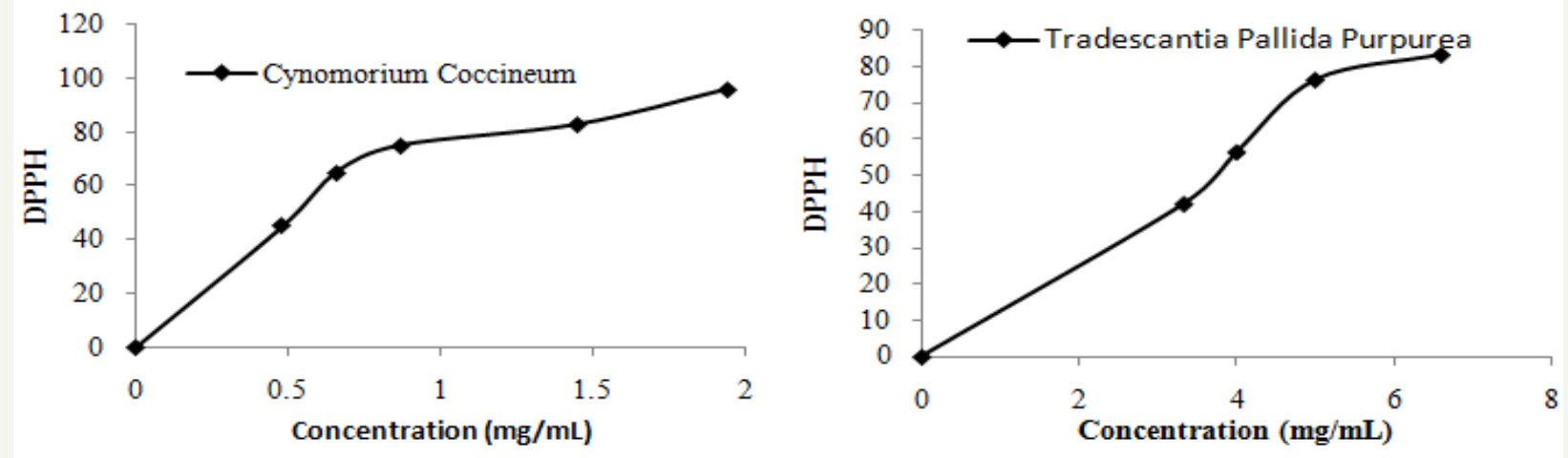

Figure 3: The ability of Tradescantia pallida purpurea and Cynomorium coccineum extracts to quench reactive species through the $\mathrm{DPPH}^{*}$ radical scavenging activity assay.

\section{Conclusion}

To sum up, the methanolic extracts of Tradescantia pallida purpurea and Cynomorium coccineum were chemically characterized for their total phenolic contents, total flavanoid contents and for their ability to quench reactive species through the $\mathrm{DPPH}^{*}$ radical scavenging. Data revealed that the dosage experiments of TPC values allows us to conclude that the polyphenolic compounds are the most important functional components found in the two studied plants. These aqueous extracts are, also, rich with flavonoids which are generally known for their coloring power for textile materials. Further works will be extended for the investigation of the full dyeing properties of the textile clothing using these studied methanolic extracts. The extraction process will also be optimized using various sorts of solvents.

\section{References}

1. Teresa SP, Sanchez BMT (2007) Anthocyanins: from plant to health. Phytochemistry Reviews 7(2): 281-299.

2. Suwalsky M, Vargas P, Avello M, Villena F, Sotomayor CP (2008) Human erythrocytes are affected in vitro by flavonoids of Aristotelia chilensis (Maqui) leaves. Int J Pharm 363: 85-90.

3. Kayesh E, Shangguan L, Korir NK, Sun X, Bilkish N, et al. (2013) Fruit skin color and the role of anthocyanin. Acta Physiol Plant 35(10): 2879-2890.

4. Santos APM, Segura Muñoz SI, Nadal M, Schuhmacher M, Domingo JL, et al. (2015) Traffic-related air pollution biomonitoring with Tradescantia pallida (rose) Hunt. cv. purpurea Boom in Brazil. Environ Monit Assess 187(2): 39.

5. Vanessa M, Sthanley R, Jaqueline OBT, Andrea A, Djalmir NM, et al (2016) Preliminary spectroscopic and thermo-optical characterization of anthocyanin unpurified crude extracted from Tradescantia pallida Purpurea. Dyes and Pigments 135: 57-63.

6. Jing P, Bomser JA, Schwartz SJ, He J, Magnuson BA, et al. (2008) Structurefunction relationships of anthocyanins from various anthocyaninrich extracts on the inhibition of colon cancer cell growth. J Agric Food Chem 56(20): 9391-9398.

7. Baublis AJ, Berber Jiménez MD (1995) Structural and conformational characterization of a stable anthocyanin from Tradescantia pallida. J Agric Food Chem 43(3): 640-646.

8. Abd el Rahman HA, el Badry AA, Mahmoud OM, Harraz FA (1999) The effect of the aqueous extract of Cynomorium coccineum on the epididymal sperm pattern of the rat. Phytother 13(3): 248-250.

9. Dharmananda S (2011) Cynomorium-Parasitic plant widely used in traditional medicine.

10. Duke JA, Duke PAK, du Cellier JL (2008) Duke's Handbook of Medicinal Plants of the Bible. ( $1^{\text {st }}$ edn), CRC Press, Boca Raton, FL, USA, p. 552

11. Heestra H, Al Hassan H, Minwer F (1990) Plants of the Northern Saudi Arabia, an Illustrated Guide. Range and Animal Development Centre Publications, Skaka, Saudi Arabia, pp. 170-171.

12. Ageel AM, Mossa JS, Tariq M, Al Yahya MA, Al Said MS (1987) Saudi Plants Used in Folk Medicine. KACST, Riyadh, Saudi Arabia, p. 24.

13. Ikram M, Dar MS and Fakouhi T (1978) Hypotensive agent from Cynomorium coccineum. Pahlavi Med J 9(2): 167-181.

14. Abd El Rahman HA, El Badry AA, Mahmoud OM, Harraz FA (1999) The effect of aqueous extract of $C$. coccineum on the epididymal sperm pattern of the rat. Phytother 13(3): 248-250.

15. Al Qarawi AA, Abdel Rahman HA, El Badry AA, Harraz F, Razig NA, et al. (2000) The effect of extracts of Cynomorium coccineum and Withania somnifera on gonadotrophins and ovarian follicles of immature wistar rats. Phytother 14(4): 288-290. 
16. Rached W, Benamar H, Bennaceur M, Marouf A (2010) Screening of the antioxidant potential of some Algerian indigenous plants. J Biol Sci 10(4): 316-324.

17. Abdel Magied EM, Abdel Rahman HA, Harraz FM (2001) The effect of aqueous extracts of Cynomorium coccineum and Withania somnifera on testicular development in immature Wistar Rats. J Ethnopharmacol 75(1): 1-4.

18. Antonella R, Antonio R, Alessandra P, Angela A, Paola S (2012) Chemical composition and effect on intestinal Caco-2 cell viability and lipid profile of fixed oil from Cynomorium coccineum L. Food and Chemical Toxicology 50(10): 3799-3807

19. Bursal E, Gülçin İ (2011) Polyphenol contents and in vitro antioxidant activities of lyophilized aqueous extract of kiwi fruit (Actinidiadeliciosa). Food Research International 44: 1482-1489.

20. Sun L, Zhang J, Lu X, Zhang L, Zhang Y (2011) Evaluation to the antioxidant activity of total flavonoids extract from persimmon (Diospyros kaki L) leaves. Food Chem Toxicol 49(10): 2689-2696.

21. Yu L, Zhao M, Wang JS, Cui C, Yang B, et al. (2008) Antioxidant, immunomodulatory, andante-breast cancer activities of phenolic extract from pine (Pinusmassoniana Lamb.) bark. Innovative Food Science and Emerging Technologies 9(1): 122-128.

22. Noureddine B, Wafa H, Manel BT, Maria TPA, Mohamed FM (2017) Sustainability issues of ultrasonic wool dyeing with grape pomace colourant. Natural Product Research 31(14): 1655-1662.
Creative Commons Attribution 4.0

International License
Submit Article

\section{Your subsequent submission with Crimson Publishers will attain the below benefits}

- High-level peer review and editorial services

- Freely accessible online immediately upon publication

- Authors retain the copyright to their work

- Licensing it under a Creative Commons license

- Visibility through different online platforms

- Global attainment for your research

- Article availability in different formats (Pdf, E-pub, Full Text)

- Endless customer service

- Reasonable Membership services

- Reprints availability upon request

- One step article tracking system 